\title{
Identification of neck circumference cut-off points for insulin resistance as a marker in adolescents
}

\author{
Identificação de pontos de corte da circunferência \\ do pescoço como marcador da resistência \\ à insulina em adolescentes
}

\author{
Ingrid Ribeiro da Cruz MELO1 1 iD) 0000-0002-1494-6767 \\ Márcia Ferreira Cândido de SOUZA ${ }^{1}$ [D] 0000-0001-6812-2336 \\ Íkaro Daniel de Carvalho BARRETO² ID 0000-0001-7253-806X \\ Danielle Góes da SILVA3 ${ }^{3}$ 0000-0002-2859-0853 \\ Ricardo Queiroz GURGEL1 ID 0000-0001-9651-3713
}

\section{A B S T R A C T}

\section{Objective}

To identify cut-off points of neck circumference measurement to predict insulin resistance in adolescents.

\section{Methods}

Cross-sectional analysis with data derived from the Study of Cardiovascular Risks in Adolescents, nationwide, multicenter, school-based survey. We evaluated 901 adolescents, aged 12 to 17, from public and private schools in two cities of

\footnotetext{
1 Universidade Federal de Sergipe, Programa de Pós-Graduação em Ciências da Saúde, Hospital Universitário de Sergipe. R. Cláudio Batista, s/n., Cidade Nova, 49060-108, Aracaju, SE, Brasil. Correspondence to: MFC SOUZA. E-mail: <nutrimarciacandido@gmail.com>.

2 Universidade Federal Rural de Pernambuco, Departamento de Estatística e Informática, Programa de Pós-Graduação em Biometria e Estatística Aplicada. Recife, PE, Brasil.

3 Universidade Federal de Sergipe, Departamento de Nutrição, Programa de Pós-graduação em Ciências da Nutrição. São Cristóvão, SE, Brasil.

Article elaborated from dissertation by IRC MELO, entitled "Identification of Neck Circumference Cut-Off Points for Insulin Resistance as a Marker in Adolescents”. Universidade Federal de Sergipe; 2020.

Support: Conselho Nacional de Desenvolvimento Científico e Tecnológico (CNPq, National Council for Scientific and Technological Development) (Process n. 130541/2018-4); Coordenação de Aperfeiçoamento de Pessoal de Nível Superior (CAPES, Coordination of Superior Level Staff Improvement).
}

How to cite this article

Melo IRC, Souza MFC, Barreto IDC, Silva DG, Gurgel RQ. Identification of neck circumference cut-off points for insulin resistance as a marker in adolescentes. Rev Nutr. 2020;34:e200190. https://doi.org/10.1590/1678-9865202134e200190 
Sergipe state in Brazil. We measured demographic, anthropometric, and biochemical data, and insulin resistance using Homeostasis Model Assessment-Insulin Resistance. We used multiple linear regression and logistic analysis to evaluate the association between dependent variables (biochemical) and independent variables (anthropometric) controlled by body mass index, age, gender, and Tanner's stage. We used the Receiver operating characteristic curve to determine cut-off points of neck circumference that can identify insulin resistance.

\section{Results}

The multiple linear regression analysis showed a positive association between neck circumference measurement with fasting glycemia and glycated hemoglobin $(p<0.001)$ and a negative association with insulin $(p<0.024)$. Furthermore, in logistic regression, the measurement of neck circumference was the only anthropometric indicator positively correlated with homeostasis model assessment-insulin resistance. The cut-off points of neck circumference for predicting insulin resistance were: $30.55 \mathrm{~cm}$ for female pubertal and $32.10 \mathrm{~cm}$ for post-pubertal adolescents; $35.90 \mathrm{~cm}$ for male pubertal adolescents and $36.65 \mathrm{~cm}$ for post-pubertal adolescents.

\section{Conclusion}

The measurement of neck circumference is a simple, practical anthropometric indicator and can be used as a screening tool to identify insulin resistance in adolescents.

Keywords: Adolescent. Anthropometry. Insulin resistance. Neck.

\section{R E S U M O}

\section{Objetivo}

Identificar pontos de corte da medida da circunferência do pescoço que possam predizer a resistência à insulina em adolescentes.

\section{Métodos}

Estudo transversal com uma subamostra do Estudo de Riscos Cardiovasculares em Adolescentes, um estudo multicêntrico nacional. Avaliaram-se 901 adolescentes de 12 a 17 anos de duas cidades do estado de Sergipe, Brasil. Fatores demográficos, antropométricos e bioquímicos e a resistência à insulina pelo homeostasis model assessment-insulin resistance foram mensurados. A associação entre as variáveis dependentes (bioquímicas) e independentes (antropométricas), controladas pelo índice de massa corporal, idade, sexo e estadiamento de Tanner, foi avaliada pela análise de regressão linear múltipla e logística, e a curva característica de operação do receptor foi utilizada para determinar os pontos de corte da circunferência do pescoço na predição da resistência à insulina.

\section{Resultados}

A análise de regressão linear múltipla mostrou uma associação positiva entre a medida da circunferência do pescoço com a glicemia de jejum e a hemoglobina glicada $(p<0,001)$ e negativa com a insulina $(p<0,024)$. Na regressão logística, a medida da circunferência do pescoço foi o único indicador antropométrico que se correlacionou positivamente com o Homeostasis Model Assessment-Insulin Resistance. Os pontos de corte da circunferência do pescoço para predição da resistência à insulina em adolescentes foram: 30,55cm feminino púberes e 32,10cm feminino pós-púberes; $35,90 \mathrm{~cm}$ masculino púberes e $36,65 \mathrm{~cm}$ masculino pós-púberes.

\section{Conclusão}

A medida da circunferência do pescoço é um indicador antropométrico simples e prático e pode ser utilizada como instrumento de triagem para identificar a resistência à insulina em adolescentes.

Palavras-chave: Adolescente. Antropometria. Resistência à insulina. Pescoço.

\section{NTRODUCTION}

The measurement of Neck Circumference (NC) has been proposed as a metabolic risk marker for obesity for a few years [1,2]. When compared to standard anthropometric measurements, such as Body Mass Index (BMI) and Waist Circumference (WC), NC has advantages like simplicity, low cost, easy to apply, and little exposure to the person evaluated $[1,2]$. 
The upper body subcutaneous fat estimated by NC may represent a higher cardiometabolic risk in comparison to abdominal visceral fat [3]. Elevated systemic Free Fatty Acids (FFA), determined by upper body subcutaneous fat, may play an important role in some metabolic disorders, such as oxidative stress and Insulin Resistance (IR) [4].

Insulin Resistance consists of the decrease of glucose capture, mediated by insulin, in organic target tissues. As a consequence, high glucose can generate hyperglycemia, providing a systemic inflammatory response that can result in the development of chronic diseases such as diabetes Mellitus type 2 (DM2), hypertension, and dyslipidemias [5]. This IR is related to visceral and subcutaneous fat and is a relevant disorder marker among the younger populations $[6,7]$.

Some factors such as physical inactivity, excessive weight gain, gender, stage of sexual maturation, and race are physiological conditions that can favor the development of IR in adolescence [8]. In Brazil, data show that the prevalence of insulin resistance in adolescents is $27.0 \%$ being more observed in the southern region of the country (35.9\%) and less observed in the central-western region (19.8\%) [9].

In adults, some studies presented a positive correlation between NC and IR but studies are still scarce in adolescents $[10,11]$. Therefore, the goal of this work is to explore the importance of NC measurements as an additional tool for the assessment of early IR identification and development of type 2 diabetes Mellitus in adolescents. More precisely, we investigate cut-off points on the neck circumference that can predict insulin resistance in adolescents aged 12 to 17 years.

\section{METHODS}

In this work, we performed a cross-sectional analysis with data derived from the Study of Cardiovascular Risks in Adolescents (ERICA Study), a nationwide, multicenter, school-based survey, conducted in 2013-2014. ERICA Study has estimated the prevalence of metabolic syndrome and other cardiovascular risk factors in Brazilian adolescents. The ERICA study assessed more than 75,000 students between 12 and 17 years of age, from 1,248 public and public schools distributed in Brazilian municipalities with over 100,000 inhabitants [12].

This study corresponds to a subsample from ERICA's project of adolescents aged 12 to 17 years, enrolled in schools from Aracaju, and Nossa Senhora do Socorro, two cities of Sergipe state, Northeast Brazil. The sample may be considered to have local representativity.

For ERICA's project sample procedure in Sergipe, selected twenty-nine public and private schools, twenty-six located in Aracaju and three in Nossa Senhora do Socorro, the second municipality with over 100,000 inhabitants in Sergipe State. A survey using the class year as a proxy of age took place in order to select eligible classes $\left(7^{\text {th }}, 8^{\text {th }}, 9^{\text {th }}\right.$ years of elementary school and $1^{\text {st }}, 2^{\text {nd }}$, and $3^{\text {rd }}$ years of high school) and which allowed three classes to be chosen from each school [12].

Participation in the data collection included all the eligible adolescents with a consent form signed by their primary caregiver. However, the study excluded individuals with masses or deformities in the neck; goiter; delayed neuro-psych motor development; genetic syndromes; hepatopathy; nephropathy; metabolic disorders, such as hypothyroidism, hyperthyroidism; and in use of systemic corticoids.

We evaluated 1,474 adolescents in the cities of Aracaju and Nossa Senhora do Socorro. However, for the final sample, we considered only adolescents of the pubertal staging classification as pubertal and post-pubertal, who performed the collection of biochemical tests. The final sample was composed of 901 adolescents. 
Assessments included anthropometric measurements (weight, height, BMI, WC, and NC), and biochemical analyses. A team previously trained for ERICA Study collected the anthropometric measurements, except NC. Undergraduate students in nutrition, also previously trained, measured NC in adolescents.

The research ethics committees from Universidade Federal do Rio de Janeiro (UFRJ, Federal University of Rio de Janeiro) and Universidade Federal de Sergipe (UFS, Federal University of Sergipe) approved the ERICA project under numbers 0027.0.239.000-08 and 560.079-0, respectively. This project is an addendum to the one approved at the local level.

The methods sections of previous studies provide a complete description of methods and technical specifications of anthropometric evaluation instruments [12,13]. In this study, we describe only the criteria adopted to analyze the results of these measures.

The body mass index was evaluated by calculating the BMI [weight $\left.(\mathrm{kg}) / \mathrm{height}\left(\mathrm{m}^{2}\right)\right]$ by age $(\mathrm{BMl} / \mathrm{A})$, followed the cut-off points of the World Health Organization curves: Z-score <-3 (malnutrition); Z-score $\geq-3$ and $<-2$ (low weight); Z-score $\geq-2$ and $<1$ (normal weight); Z-score $>1$ and $\leq 2$ (overweight); Z-score $>2$ (obesity) [14].

The analysis of WC risk increase followed the recommended cut-off points of the International Diabetes Federation: $<16$ years: $\geq 90$ percentile; $\geq 16$ years: male: $\geq 90 \mathrm{~cm}$; female: $\geq 80 \mathrm{~cm}$ [15]. The Waist-to-Height Ratio (WHtR) was given by dividing the waist circumference by the height in centimeters, and has a cut-off point of $<0.5$.

We measured the NC, just below the cricoid cartilage, with the adolescent standing and the head positioned in the Frankfurt horizontal plane. Furthermore to calculate technical error and maintain accuracy and precision, we measured NC three times and recorded its mean by the standardization of Habicht's technique [16]. The coefficient of variation of the NC found was 1.26 to $3.14 \%$.

Sexual maturation was self-reported by the adolescents, and recorded in an electronic data collector, the Personal Digital Assistant (PDA), as proposed by Tanner [17]. Tanner's criteria for classification are pre-pubertal, adolescents in stage I, pubertal adolescents in stages II, III and IV, and post-pubertal adolescents in stage $\mathrm{V}[17]$.

A single laboratory hired by ERICA performed all the biochemical collection of the study. The reference values for the biochemical tests were similar to those of the ERICA project [13]. In this study, we used only biochemical data regarding fasting glycemia, fasting insulin, and glycated hemoglobin. Moreover, due to the need for 12-hour fasting, only morning students participated in the collection.

We calculated the Homeostasis Model Assessment-Insulin Resistance (HOMA-IR) measurement with the fasting glucose and insulin values, obtained through the formula: HOMA-IR = (Fasting InsulinemiaXFasting Glucose)/22.5. The cut-off point adopted was established from the $75^{\text {th }}$ percentile of the sample evaluated according to sex and pubertal stage. The values found were:HOMA-IR 2.31 and HOMA-IR 2.57 for pubertal and post-pubertal female adolescents and HOMA-IR 2.03 and HOMA-IR 1.97 for pubertal and post-pubertal male adolescents, respectively.

We used R Core Team 2020 to analyze the data. For the descriptive data, we calculated medians and interquartile intervals related to age, anthropometric, and biochemical variables. We used the Mann-Whitney test to compare measures of central tendency between groups of adolescents divided by sex and pubertal stage and chi-square test to verify the association between categorical variables. Moreover, Spearman's correlation coefficient also used to evaluate the association between NC, WC, WHtR, and BMI with values of biochemical tests. The interpretations are no correlation $(p<0.1)$; weak $(0.1 \leq p<0.4)$; moderate $(0.4 \leq p<0.7)$; or strong $(p>0.7)$. 
Furthermore, we used multiple linear regression to evaluate the relationship between dependent variables (biochemical) and independent variables (anthropometric). The variables were controlled by BMI, age, gender, and Tanner's stage. We reported measures of determination ( $R^{2}$; adjusted $R^{2}$ ), coefficients and their respective confidence intervals, as well as standardized coefficients ( $\beta$ ), and the Variance Inflation Factors (VIF). We used a T-test to evaluate the significance of the coefficients.

We used a logistic regression model to evaluate the performance of the anthropometric and variable measures of the above-mentioned controls against the HOMA-IR categorized by p75. We estimated controlled odds ratio and confidence intervals tested by Wald's test.

We used the Receiver Operating Characteristic Curve (ROC) to analyze the predictive validity of NC. Moreover, we used the determination of cut-off points to predict insulin resistance in the sampled adolescents, and the Youden index as the criterion for defining the cut-off points.

Finally, we calculated the Area Under the Curve (AUC), and the sensitivity and specificity values for each point. The AUC demonstrates the probability of correctly identifying individuals with IR. The Kolmogorov-Smirnov test checked all test normality with a $5 \%$ significance level $(p<0.05)$.

\section{RE S U L T S}

The sampled adolescents had a mean age of $14.7 \pm 1.5$ years, and 518 (57.5\%) were female. Most of the sampled adolescents (56.3\%) were in high school and attended the private education network (52.4\%).

According to the classification of the nutritional status by BMI, $16.0 \%(n=144)$ of the sample was overweight, being higher $(17.4 \%)$ in female adolescents $(n=90)$. About obesity, $8.3 \%(n=75)$ of the adolescents were obese, with a higher proportion among male adolescents $(p=0.029)$. Table 1 describes the general, anthropometric, and biochemical characterization of the studied sample.

Table 1. Characterization of the study sample adolescents from public and private schools from Aracaju and Nossa Senhora do Socorro according to sex and pubertal stage $(n=901)$. Sergipe, Brazil, 2013-2014.

of 2

\begin{tabular}{|c|c|c|c|c|c|c|c|c|c|}
\hline \multirow{4}{*}{ Variables } & \multicolumn{6}{|c|}{ Pubertal staging } & & & \\
\hline & \multicolumn{3}{|c|}{ Pubertal } & \multicolumn{3}{|c|}{ Post-Pubertal } & \multicolumn{3}{|c|}{ Total } \\
\hline & Female & Male & $p$-value & Female & Male & $p$-value & Female & Male & $p$-value \\
\hline & $\mathrm{n}(\%)^{*}$ & $\mathrm{n}(\%)^{*}$ & & $\mathrm{n}(\%)^{*}$ & $\mathrm{n}(\%)^{\star}$ & & $\mathrm{n}(\%)^{*}$ & $\mathrm{n}(\%)^{*}$ & \\
\hline \multicolumn{10}{|l|}{ Scholl type } \\
\hline Public & $143(49.5)$ & $105(44.9)$ & $0.294^{\dagger}$ & $106(46.3)$ & $75(50.3)$ & $0.441^{\dagger}$ & $249(48.1)$ & $180(47.0)$ & $0.750^{+}$ \\
\hline \multicolumn{10}{|l|}{ Level of education } \\
\hline Elementary School & $137(47.4)$ & $130(55.6)$ & $0.064^{\dagger}$ & $78(34.1)$ & 49 (32.9) & $0.813^{\dagger}$ & $215(41.5)$ & $179(46.7)$ & $0.118^{\dagger}$ \\
\hline High School & $152(52.6)$ & $104(44.4)$ & & $151(65.9)$ & $100(67.1)$ & & $303(58.5)$ & $204(53.3)$ & \\
\hline \multicolumn{10}{|l|}{ Age (years) } \\
\hline $12-14$ & $158(54.7)$ & $134(53.0)$ & $0.702^{\dagger}$ & $88(38.4)$ & $47(31.5)$ & $0.172^{\dagger}$ & $246(47.5)$ & $171(44.6)$ & $0.398^{\dagger}$ \\
\hline $15-17$ & $131(45.3)$ & $110(47.0)$ & & $141(61.6)$ & $102(68.5)$ & & $272(52.5)$ & $212(55.4)$ & \\
\hline Low Weight & $11(3.8)$ & $15(6.4)$ & $0.002^{\dagger}$ & $3(1.3)$ & $5(3.4)$ & 0.265 & $14(2.7)$ & $20(5.2)$ & $0.029^{\dagger}$ \\
\hline Normal Weight & $222(75.8)$ & $159(67.9)$ & & $157(68.6)$ & $110(68.6)$ & & $379(73.2)$ & $269(70.2)$ & \\
\hline Overweight & $43(14.9)$ & $30(12.8)$ & & $47(20.5)$ & $24(16.1)$ & & $90(17.4)$ & $54(14.1)$ & \\
\hline Obesity & $13(4.5)$ & $30(12.8)$ & & $22(9.6)$ & $10(6.7)$ & & $35(6.8)$ & $40(10.4)$ & \\
\hline Anthro. measures & $\mathrm{M}(\mathrm{IQR})$ & $M(I Q R)$ & & $M(I Q R)$ & $M(I Q R)$ & & $M(I Q R)$ & $M(I Q R)$ & \\
\hline Weight (kg) & 50.2 & 55.8 & $<0.001^{t+}$ & 55.7 & 59.4 & $<0.001^{t \dagger}$ & 52.2 & 57.3 & $<0.001^{\dagger \dagger}$ \\
\hline & $(44.1-57.1)$ & $(46.3-67.5)$ & & $(48.6-63.4)$ & $(52.5-70.4)$ & & $(45.5-59.6)$ & $(49-68.5)$ & \\
\hline
\end{tabular}


Table 1. Characterization of the study sample adolescents from public and private schools from Aracaju and Nossa Senhora do Socorro according to sex and pubertal stage $(n=901)$. Sergipe, Brazil, 2013-2014.

2 of 2

\begin{tabular}{|c|c|c|c|c|c|c|c|c|c|}
\hline \multirow{3}{*}{ Variables } & \multicolumn{6}{|c|}{ Pubertal staging } & & & \\
\hline & \multicolumn{3}{|c|}{ Pubertal } & \multicolumn{3}{|c|}{ Post-Pubertal } & \multicolumn{3}{|c|}{ Total } \\
\hline & $\begin{array}{l}\text { Female } \\
\mathrm{n}(\%)^{*}\end{array}$ & $\begin{array}{c}\text { Male } \\
\mathrm{n}(\%)^{*}\end{array}$ & $p$-value & $\begin{array}{l}\text { Female } \\
\mathrm{n}(\%)^{*}\end{array}$ & $\begin{array}{c}\text { Male } \\
\mathrm{n}(\%)^{*}\end{array}$ & $p$-value & $\begin{array}{l}\text { Female } \\
\mathrm{n}(\%)^{*}\end{array}$ & $\begin{array}{c}\text { Male } \\
n(\%)^{*}\end{array}$ & $p$-value \\
\hline $\mathrm{BMI}\left(\mathrm{kg} / \mathrm{m}^{2}\right)$ & $\begin{array}{c}19.4 \\
(17.4-22.5)\end{array}$ & $\begin{array}{c}20.1 \\
(17.4-23)\end{array}$ & $0.244^{t \dagger}$ & $\begin{array}{c}21.6 \\
(19.5-24.4)\end{array}$ & $\begin{array}{c}20.5 \\
(18.5-23.4)\end{array}$ & $0.006^{t+}$ & $\begin{array}{c}20.4 \\
(18.2-23.3)\end{array}$ & $\begin{array}{c}20.3 \\
(17.9-23.2)\end{array}$ & $0.329^{t t}$ \\
\hline WC $(\mathrm{cm})$ & $\begin{array}{c}67.2 \\
(63-72.3)\end{array}$ & $\begin{array}{c}70.3 \\
(64.8-77.1)\end{array}$ & $<0.001^{\text {tt }}$ & $\begin{array}{c}70.8 \\
(65.3-76.8)\end{array}$ & $\begin{array}{c}71.1 \\
(68-79)\end{array}$ & $0.079^{t t}$ & $\begin{array}{c}68.5 \\
(64.3-73.9)\end{array}$ & $\begin{array}{c}70.5 \\
(66.1-78.4)\end{array}$ & $<0.001^{t+}$ \\
\hline $\mathrm{NC}(\mathrm{cm})$ & $\begin{array}{c}30.3 \\
(29.4-31.6)\end{array}$ & $\begin{array}{c}32.5 \\
(31-35.6)\end{array}$ & $<0.001^{t+}$ & $\begin{array}{c}30.9 \\
(30-32.2)\end{array}$ & $\begin{array}{c}34.3 \\
(32.8-36.8)\end{array}$ & $<0.001^{\text {tt }}$ & $\begin{array}{c}30.5 \\
(29.6-32)\end{array}$ & $\begin{array}{c}33.9 \\
(32-36.1)\end{array}$ & $<0.001^{t+}$ \\
\hline WHtR $(\mathrm{cm})$ & $\begin{array}{c}0.425 \\
(0.39-0.45)\end{array}$ & $\begin{array}{c}0.422 \\
(0.4-0.46)\end{array}$ & $0.317^{t t}$ & $\begin{array}{c}0.443 \\
(0.41-0.47)\end{array}$ & $\begin{array}{c}0.415 \\
(0.399-0.45)\end{array}$ & $<0.001^{\text {tt }}$ & $\begin{array}{c}0.433 \\
(0.40-0.46)\end{array}$ & $\begin{array}{c}0.419 \\
(0.4-0.46)\end{array}$ & $0.047^{t+}$ \\
\hline Biochemical Tests & & & & & & & & & \\
\hline FPG (mg/dL) & $\begin{array}{c}84 \\
(80-88)\end{array}$ & $\begin{array}{c}85 \\
(81-89)\end{array}$ & $0.033^{t t}$ & $\begin{array}{c}82 \\
(79-87)\end{array}$ & $\begin{array}{c}85 \\
(81-90)\end{array}$ & $<0.001^{t t}$ & $\begin{array}{c}83 \\
(79-88)\end{array}$ & $\begin{array}{c}85 \\
(81-89)\end{array}$ & $<0.001^{t+}$ \\
\hline $\mathrm{HbA1c}(\mathrm{mg} / \mathrm{dL})$ & $\begin{array}{c}5.4 \\
(5.2-5.6)\end{array}$ & $\begin{array}{c}5.4 \\
(5.2-5.7)\end{array}$ & $0.203^{t t}$ & $\begin{array}{c}5.4 \\
(5.2-5.6)\end{array}$ & $\begin{array}{c}5.4 \\
(5.2-5.6)\end{array}$ & $0.632^{t+}$ & $\begin{array}{c}5.4 \\
(5.2-5.6)\end{array}$ & $\begin{array}{c}5.4 \\
(5.2-5.6)\end{array}$ & 0.443 \\
\hline Insulin (IU/mL) & $\begin{array}{c}8.2 \\
(6.3-11)\end{array}$ & $\begin{array}{c}7.1 \\
(4.7-9.8)\end{array}$ & $<0.001^{t t}$ & $\begin{array}{c}8.8 \\
(6.2-12.2)\end{array}$ & $\begin{array}{c}6.8 \\
(4.5-9.4)\end{array}$ & $<0.001^{t \dagger}$ & $\begin{array}{c}8.4 \\
(6.2-11.4)\end{array}$ & $\begin{array}{c}6.9 \\
(4.6-9.5)\end{array}$ & $<0.001^{t+}$ \\
\hline HOMA-IR & $\begin{array}{c}1.7 \\
(1.25-2.31)\end{array}$ & $\begin{array}{c}1.46 \\
(0.97-2.03)\end{array}$ & $<0.001^{t+}$ & $\begin{array}{c}1.78 \\
(1.23-2.57)\end{array}$ & $\begin{array}{c}1.4 \\
(0.95-1.97)\end{array}$ & $<0.001^{\text {tt }}$ & $\begin{array}{c}1.73 \\
(1.24-2.41)\end{array}$ & $\begin{array}{c}1.44 \\
(0.95-2)\end{array}$ & $<0.001^{t+}$ \\
\hline
\end{tabular}

Note: $\mathrm{n}$ : Absolute frequency; ${ }^{*}$ Relative frequency by percentage. ${ }^{\dagger}$ Pearson's Chi-square test $p<0.05 ;{ }^{\dagger \dagger}$ Mann-Whitney test $p<0.05$.

Anthro measures: Anthropometric Measures; BMI: Body Mass Index; FGP: Fasting Glucose Level; HbA1c: Glycated Hemoglobin; HOMA-IR: Homeostasis Model Assessment-Insulin Resistance. IQR: Interquartile Range; M: Median; NC: Neck Circumference; WC: Waist Circumference; WHtR: Waist-to-Height Ratio.

Table 2 shows the correlation between glycemic markers and anthropometric indicators according to gender. The results showed a significant correlation with NC, insulin, and HOMA-IR among female adolescents, a result comparable with the other anthropometric indicators evaluated. In male adolescents, there was no correlation between the NC and glycemic markers.

After adjustments for BMI, gender, and Tanner stage, multiple linear regression analysis showed that the NC measure was positively correlated with fasting glycemia and $\mathrm{HbA} 1 \mathrm{c}(p<0.001)$ and negatively with insulin $(p<0.024)$. In logistic regression, NC measurement was the only anthropometric indicator that associated positively with HOMA-IR (Table 3).

Table 2. Correlation between glycemic markers and anthropometric indicators according to gender of students aged 12 to 17 years from public and private schools in Aracaju and Nossa Senhora do Socorro (SE), Brazil, 2013-2014.

\begin{tabular}{|c|c|c|c|c|c|c|c|c|}
\hline \multirow{2}{*}{ Variables } & \multicolumn{4}{|c|}{ Female } & \multicolumn{4}{|c|}{ Male } \\
\hline & $\mathrm{BMI}$ & $\mathrm{NC}$ & WC & WHtR & $\mathrm{BMI}$ & $\mathrm{NC}$ & WC & WHtR \\
\hline $\mathrm{FGP}(\mathrm{mg} / \mathrm{dL})$ & 0.014 & -0.022 & 0.038 & 0.069 & 0.073 & -0.019 & 0.034 & 0.105 \\
\hline $\mathrm{HbA} 1 \mathrm{c}(\mathrm{mg} / \mathrm{dL})$ & 0.011 & -0.024 & 0.050 & 0.050 & 0.019 & -0.011 & -0.023 & -0.015 \\
\hline Insulin (UI/mL) & $0.248^{* *}$ & $0.218^{* *}$ & $0.316^{* *}$ & $0.291^{* *}$ & $0.347^{* *}$ & $0.111^{*}$ & $0.372^{* *}$ & $0.427^{* *}$ \\
\hline HOMA-IR & $0.240^{* *}$ & $0.206^{* *}$ & $0.306^{* *}$ & $0.288^{* *}$ & $0.338^{* *}$ & $0.101^{*}$ & $0.357^{* *}$ & $0.415^{* *}$ \\
\hline
\end{tabular}

Note: *Spearman correlation $p<0.05$. ${ }^{* *}$ Spearman correlation $p<0.001$.

BMI: Body Mass Index; FGP: Fasting Glucose Level; HbA1c: Glycated Hemoglobin; HOMA-IR: Homeostasis Model Assessment-Insulin Resistance; NC: Neck Circumference; WC: Waist Circumference; WHtR: Waist-to-Height Ratio. 
Table 3. Multiple linear regression analysis and logistic regression between glycemic markers and anthropometric indicators of students aged 12 to 17 years from public and private schools in Aracaju and Nossa Senhora do Socorro (SE), Brazil, 2013-2014.

\begin{tabular}{|c|c|c|c|c|c|c|c|c|}
\hline Dependent variable & Independent variable & $\mathrm{R}^{2}$ & $R^{2}$ adj & B & $\mathrm{C} 195 \%$ & $\beta$ & $p$-value* & VIF \\
\hline \multirow[t]{3}{*}{$\mathrm{FGP}(\mathrm{mg} / \mathrm{dl})^{*}$} & WC & 0.985 & 0.985 & -0.28 & $-0.52 ;-0.03$ & -0.234 & 0.027 & 660.93 \\
\hline & NC & & & 2.00 & $1.74 ; 2.26$ & 0.757 & $<0.001$ & 147.53 \\
\hline & WHTR & & & 169.03 & $133.86 ; 204.19$ & 0.874 & $<0.001$ & 508.09 \\
\hline \multirow[t]{3}{*}{$\mathrm{HbA} 1 \mathrm{c}(\mathrm{mg} / \mathrm{dl})^{*}$} & WC & 0.990 & 0.990 & -0.01 & $-0.02 ; 0.004$ & -0.112 & 0.184 & 660.93 \\
\hline & NC & & & 0.13 & $0.11 ; 0.14$ & 0.754 & $<0.001$ & 147.53 \\
\hline & WHtR & & & 8.09 & $6.31 ; 9.87$ & 0.659 & $<0.001$ & 508.09 \\
\hline \multirow[t]{3}{*}{ Insulina $(\mathrm{Ul} / \mathrm{ml})^{*}$} & WC & 0.447 & 0.443 & 0.19 & $-0.06 ; 0.45$ & 0.935 & 0.144 & 660.93 \\
\hline & NC & & & -0.31 & $-0.58 ;-0.04$ & -0.685 & 0.024 & 147.53 \\
\hline & WHtR & & & 22.24 & $-14.29 ; 58.76$ & 0.670 & 0.232 & 508.09 \\
\hline \multirow[t]{4}{*}{ HOMA-IR* } & WC & 0.133 & 0.126 & 0.05 & $-0.08 ; 0.19$ & 0.618 & 0.44 & 660.93 \\
\hline & NC & & & -0.10 & $-0.24 ; 0.05$ & -0.497 & 0.19 & 147.53 \\
\hline & $\mathrm{WHtR}$ & & & 11.82 & $-7.65 ; 31.29$ & 0.837 & 0.234 & 508.09 \\
\hline & & & & OR & C195\% & & $p$-value ${ }^{* *}$ & \\
\hline \multirow[t]{3}{*}{ HOMA-IR $p 75^{* *}$} & WC & & & 1.02 & $0.95-1.09$ & & 0.545 & \\
\hline & NC & & & 1.19 & $1.01-1.41$ & & 0.033 & \\
\hline & WHtR & & & 1.03 & $0.91-1.17$ & & 0.639 & \\
\hline
\end{tabular}

Note: "Multiple linear regression; ${ }^{* *}$ Logistic Regression; ${ }^{* * *}$ In centimeters; $\beta$ : Standardized coefficient; B: Regression Coefficient; BMI: Body Mass Index; C195\%: Confidence interval; FGP: Fasting Glucose Level; HbA1c: Glycated Hemoglobin; HOMA-IR p75: Homeostasis Model Assessment-Insulin Resistance $75^{\text {th }}$ percentile; HOMA-IR: Homeostasis Model Assessment-Insulin Resistance; NC: Neck Circumference; R² and $R^{2}$ adjusted: Coefficients of determination; Values adjusted by age, sex, and Tanner staging; VIF: Inflation Factor of Variance; WC: Waist Circumference; WHtR: Waist-to-Height Ratio.

Table 4 shows the different NC cut-off points for predicting insulin resistance, their sensitivities, specificities, and predictive values. The cut-off points of NC for the prediction of insulin resistance in females were $30.55 \mathrm{~cm}$ for pubertal adolescents and $32.10 \mathrm{~cm}$ for post-pubertal adolescents. In males, the cut-off points were $35.90 \mathrm{~cm}$ for pubertal and $36.65 \mathrm{~cm}$ for post-pubertal adolescents.

In figure 1, we observe the AUC under the ROC curve for NC as a predictor of IR with statistically significant results $(p<0.001)$. In both genders, the NC showed higher AUC for IR in post-pubertal adolescents (Figure 1).

Table 4. Cut-off points of the neck circumference for insulin resistance screening in adolescents from sex and pubertal staging. Aracaju and Nossa Senhora do Socorro (SE), Brazil, 2013-2014.

\begin{tabular}{|c|c|c|c|c|c|c|c|}
\hline & \multirow{2}{*}{ Gold Standard HOMA-IR (P75) } & \multirow{2}{*}{ Cut-off points NC $(\mathrm{cm})$} & \multicolumn{4}{|c|}{$\%$} & \multirow{2}{*}{ Youden } \\
\hline & & & $S$ & $E$ & PPV & NPV & \\
\hline \multicolumn{8}{|l|}{ Female } \\
\hline Pubertal & 2.31 & 30.55 & 91.7 & 72.3 & 52.4 & 96.3 & 0.640 \\
\hline Post-pubertal & 2.57 & 32.10 & 86.0 & 85.5 & 66.2 & 94.8 & 0.714 \\
\hline \multicolumn{8}{|l|}{ Male } \\
\hline Pubertal & 2.03 & 35.90 & 62.1 & 89.8 & 66.7 & 87.8 & 0.518 \\
\hline Post-pubertal & 1.97 & 36.65 & 70.3 & 87.5 & 65.0 & 89.9 & 0.578 \\
\hline
\end{tabular}

Note: *Youden Index= Sensitivity+Specificity-1; E: Specificity; NC: Neck Circumference; HOMA-IR (P75): Homeostasis Model Assessment-Insulin Resistance (Percentil 75); PPV: Positive Predictive Value; S: Sensibility; VPN: Negative Predictive Value. 

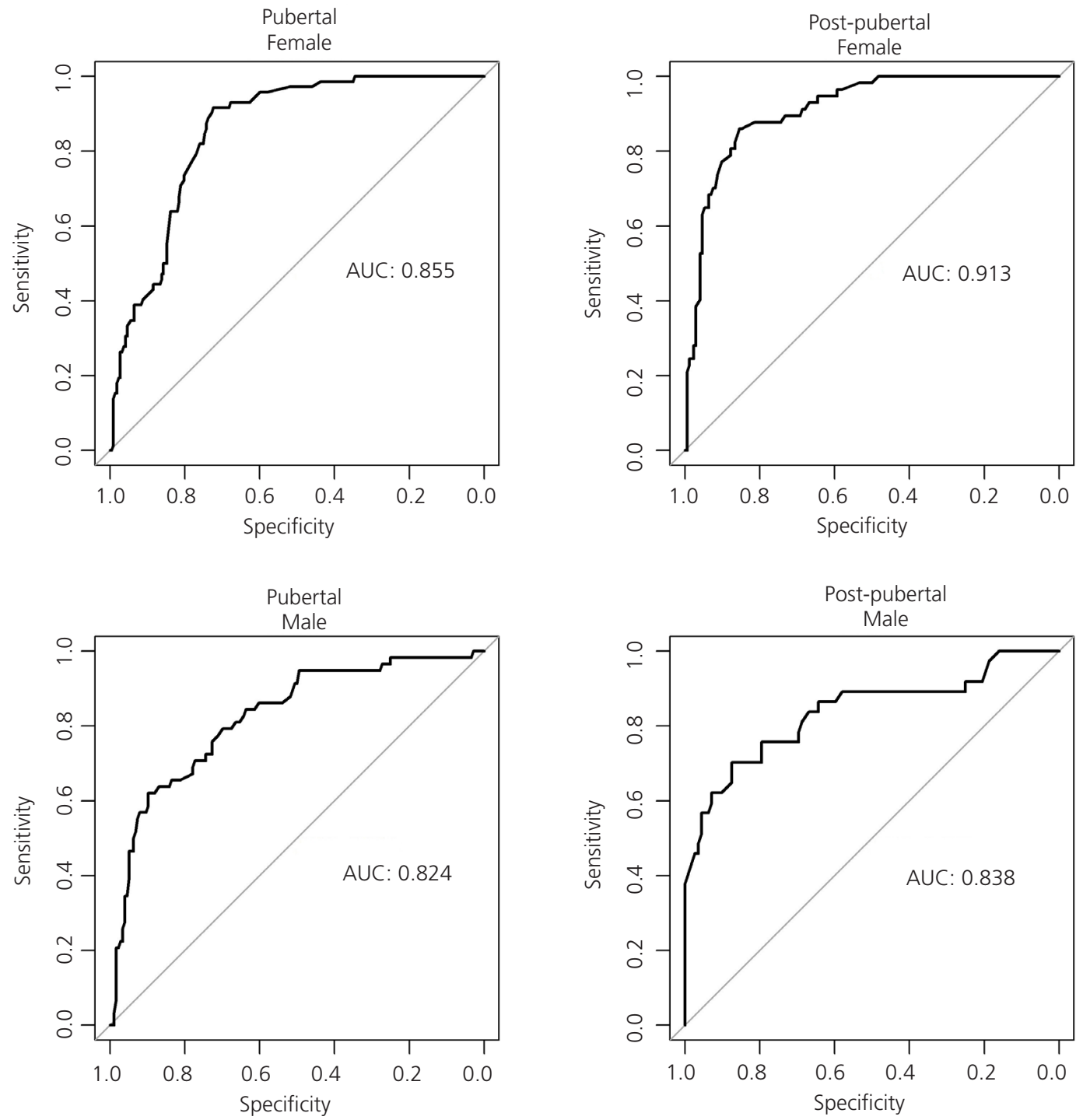

Figure 1. Cut-off points of the neck circumference for insulin resistance screening in adolescents from sex and pubertal staging.

\section{DISCUSSION}

The BMI, WC, WHtR, and NC were associated with some glycemic markers such as insulin, and HOMA-IR, especially among female adolescents. In girls, sex hormones occurs earlier when compared to boys, causing a physiological redistribution of fat from the extremities to the trunk in females $[16,18]$. This contributes to the development of the IR staff in the early stages of female adolescence [16].

The association between the NC measure and the IR markers has already been investigated in other works. Their results bring NC as a measure that can play an important role in predicting type 2 diabetes [19]. Our results show a correlation between NC with insulin and HOMA-IR in female adolescents and with insulin in male adolescents. 
In the Brazilian study by Silva et al. [20], after adjustments for \% body fat pubertal stage, the NC measurement is correlated with insulin and HOMA-IR in both genders. In our study, after adjustments for age, gender, and Tanner's stage, the measurement of NC was the only anthropometric indicator that correlates with all the glycemic markers evaluated. Also, NC showed to be better associated when compared to classic anthropometric parameters, with markers of glucose and insulin metabolism.

Thus, NC can be a part of the nutritional assessment as a screening tool for IR in adolescents [20]. The main advantage of this measure is the suitability for situations where there are equipment restrictions or cultural issues that prevent the use of traditional anthropometric measures.

Guimarães and collaborators [21], conducted a cross-sectional study with 357 adolescents from 10 to 19 years in Picos, a city in the state of Piauí. They analyzed clinical and metabolic alterations and their relationship with insulin resistance among adolescent [21]. They also found an association between NC and $I R$, in which adolescents classified with inadequate NC (30\% of the sample) had approximately 3 times more chances to develop IR. However, despite their relevant results, it is worth noting that the cut-off points of the NC adopted in this study were for overweight and not for IR.

There is still a lack of studies that explores cut-off points for NC as an IR predictor on adolescents, especially in Brazil. Gomez-Abelaez and collaborators [22] have established cut-off points for NC for the prediction of MS, low-grade systemic inflammation, and IR. They studied 669 Colombian children and adolescents between the ages of 8 and 14. The cut-off points for NC in the IR prediction and the respective sensitivity and specificity presented lower values concerning our work.

As a limitation, the authors of the Colombian study point out the sample size. They chose the pediatric Latin population, since fetal programming, associated with maternal malnutrition, still has a high prevalence in Latin America. Also, this factor could alter the body composition and the usefulness of different anthropometric measures. The authors also point out as a limitation those of the cut-off points defined from sex and not by pubertal staging [22].

In Brazil, Silva and collaborators were the pioneers to determine NC cut-off points for IR prediction in 10 to 19 years adolescents in the city of Campinas, in the state of São Paulo. The authors consider sex and pubertal staging through the ROC curve [20]. They point out as a limitation the criterion of sample selection for convenience, with a higher proportion of obese individuals. Our study does not present such a limitation.

Studies state that subclinical inflammation present in obesity is associated with the development of IR [23]. Therefore, we can infer that dietary practices in adolescence are associated with this condition, regardless of his nutritional status, changing his anthropometric profile [9].

Unlike the existing Brazilian study, we stratified our sample with the selection stage by school, class, and students, obtaining a representative sample size for the population. We selected adolescents from all BMI classification ranges, with a higher proportion of eutrophic individuals. Thus, we conducted the first study, considering gender and pubertal staging from the ROC curve, to determine the value of NC as a parameter for IR prediction in adolescents from the Northeast region of Brazil.

Our results show that NC has good sensitivity, especially among female adolescents, which are more promising than those found in the studies of Silva and collaborators [20] and Gomez-Abelaez and collaborators [22]. However, due to the lack of studies on the subject, especially with adolescents, it is not possible to further discuss and compare results.

This study presents the following limitations: (1) results are based on a cross-sectional study, which does not allow inferring casualty; (2) non-participation of the entire group of adolescents eligible for the 
sample; (3) no tests were performed that directly quantify fat deposits; (4) the stage of sexual maturation was self-reported by the adolescent, which may generate variable results in relation to the evaluation made by clinical teams.

\section{CONCLUSION}

The results found in this study show that NC is a promising screening tool for early identification of IR in Brazilian adolescents, and a relevant health indicator in adolescence. However, we point out the need for further studies, with other samples, to obtain more conclusive results.

\section{ACKNOWLEDGMENTS}

To the ERICA study for having made available the database used in this study and the Conselho Nacional de Desenvolvimento Científico e Tecnológico (CNPq, National Council for Scientific and Technological Development) for funding (Process n. 130541/2018-4).

\section{CONTRIBUTORS}

IRC MELO was the principal investigator and contributed to data collection, wrote the manuscript and approved the final version of the manuscript. MFC SOUZA contributed to interpretation of the findings and critical revision and approved the final version of the manuscript. ÍDC BARRETO contributed to the study design and data analyses. DG SILVA contributed to design and data analyses. RQ GURGEL contributed to the study design, carried out data analyses and approved the final version of the manuscript.

\section{REREFENCES}

1. Joshipura K, Muñoz-Torres F, Vergara J, Palacios $C$, Pérez CM. Neck circumference may be a better alternative to standard anthropometric measures. J Diabetes Res. 2016;2016:8.

2. Santos $D$, Contarato AAPF, Kroll C, Bertoli M, Czarnobay SA, Figueirêdo KBW, et al. Neck circumference as a complementary measure to identify excess body weight in children aged 13-24 months. Rev Bras Saúde Mater Infant. 2015;15(3):301-7.

3. Ferretti RDL, Cintra IDP, Passos MAZ, Ferrari GLDM, Fisberg M. Elevated neck circumference and associated factors in adolescents. Bmc Public Health. 2015;15(208):1-10.

4. Pandzic Jaksic V, Grizelj D, Livun A, Boscic D, Ajduk M, Kusec R, et al. Neck adipose tissue-tying ties in metabolic disorders. Horm Mol Biol Clin Investig. 2018;33(2):1-9.

5. Palhares HMC, Zaidan PC, Dib FCM, Silva AP, Resende DCS, Borges MF. Associação entre acantose nigricans e outros fatores de risco cardiometabólico em crianças e adolescentes com sobrepeso e obesidade. Rev Paul Pediatr. 2018;36(3):301-8.

6. Mutsert R, Gast K, Widya R, Koning E, Jazet I, Lamb H, et al. Associations of abdominal subcutaneous and visceral fat with insulin resistance and secretion differ between men and women: the Netherlands epidemiology of obesity study. Metab Syndr Relat Disord. 2018;16(1):54-63.

7. Caprio S, Perry R, Kursawe R. Adolescent obesity and insulin resistance: roles of ectopic fat accumulation and adipose inflammation. Gastroenterology. 2017;152(7):1638-46. https://doi.org/10.1053/j.gastro.2016.12.051

8. Kelsey MM, Zeitler PS. Insulin resistance of puberty. Curr Diab Rep. 2016;16(7). https://doi.org/10.1007/s11892016-0751-5

9. Andrade MIS. Consumo alimentar de micronutrientes antioxidantes e resistência à insulina em adolescentes brasileiros [tese]. Universidade Federal de Pernambuco; 2019. 
10. Fantin F, Comellato G, Rossi AP, Grison E, Zoico E, Mazzali G, et al. Relationship between neck circumference, insulin resistance and arterial stiffness in overweight and obese subjects. Eur J Prev Cardiol. 2017;24(14):1532-40.

11. Assyov Y, Gateva A, Tsakova A, Kamenov Z. A comparison of the clinical usefulness of neck circumference and waist circumference in individuals with severe obesity. Endocr Res. 2017;42(1):6-14. https://doi.org/10.3109/07435800.2 016.1155598

12. Vasconcellos MTL, Silva PLN, Szklo M, Kuschnir MCC, Klein CH, Abreu GDA, et al. Desenho da amostra do Estudo do Risco Cardiovascular em Adolescentes (ERICA). Cad Saúde Pública. 2015;31(5):1-10.

13. Bloch KV, Szklo M, Kuschnir MCC, Abreu GA, Barufaldi LA, Klein CH, et al. The study of cardiovascular risk in adolescents ERICA: rationale, design and sample characteristics of a national survey examining cardiovascular risk factor profile in Brazilian adolescents. Bmc Public Health. 2015;15(1):1-10.

14. Onis M, Onyango AW, Borghi E, Siyam A, Nishida C, Siekmann J. Development of a WHO growth reference for school-aged children and adolescents. Bull World Health Org. 2007;85(9):660-7.

15. Habicht J-P. Estandarizacion de metodos epidemiologicos cuantitativos sobre el terreno. Bol Sanit Panam. 1974;76(5):375-84.

16. Andrade MIS. Homa-Ir e fatores de risco cardiometabólico e consumo alimentar de adolescentes [dissertação]. Universidade Federal de Pernambuco; 2016.

17. Tanner JM. Growth at adolescence. 2nd ed. Oxford: Blackiwell; 1962.

18. Gobato AO, Carolina A, Vasques J, Zambon MP, Azevedo A, Filho B, et al. Síndrome metabólica e resistência à insulina em adolescentes obesos Metabolic syndrome and insulin resistance in obese adolescents. Rev Paul Pediatr. 2014;32(1):55-62.

19. Volaco A, Martins C, Soares J, Cavalcanti A, Moyses S, Filho R, et al. Neck circumference and its correlation to other anthropometric parameters and finnish diabetes risk score (FINDRISC). Curr Diabetes Rev. 2018;14(5):464-71.

20. Silva CC, Zambon MP, Vasques ACJ, Rodrigues AMB, Camilo DF, Antonio MÂRGM, et al. Circunferência do pescoço como um novo indicador antropométrico para predição de resistência à insulina e componentes da síndrome metabólica em adolescentes: Brazilian Metabolic Syndrome Study. Rev Paul Pediatr. 2014;32(2):221-9.

21. Guimarães MR, Alves $A$, Santos $D$, Fernanda $T$, Moura R, Rocha $M R$, et al. Alterações clínicas, metabólicas e resistência à insulina entre adolescentes. Acta Paul Enferm. 2019;32(6):608-16.

22. Gomez-Arbelaez D, Camacho PA, Cohen DD, Saavedra-Cortes S, Lopez-Lopez C, Lopez-Jaramillo P. Neck circumference as a predictor of metabolic syndrome, insulin resistance and low-grade systemic inflammation in children: The ACFIES study. Bmc Pediatr. 2016;16(1):1-9.

23. Costa CS, Rauber F, Leffa PS, Sangalli CN, Campagnolo PDB, Vitolo MR. Ultra-processed food consumption and its effects on anthropometric and glucose profile: a longitudinal study during childhood. Nutr Metab Cardiovasc Dis. 2018;29(2):177-84. https://doi.org/10.1016/j.numecd.2018.11.003 